\title{
Senator Robert Walker's 1844 Letter on Texas Annexation: The Rhetorical "Logic" of Imperialism
}

\author{
Stephen Hartnett
}

Benedict Anderson argues in Imagined Communities that "the magic of nationalism" is that it "turns chance into destiny" and "contingency into meaning." Furthermore, Anderson suggests that the production of this magic nationalism-of-destiny-and-meaning rests upon the ability to "imagine a community or nation as deep, horizontal comradeship, regardless of actual inequality and exploitation." Senator Robert J. Walker's 1844 Letter on Texas Annexation epitomizes both aspects of this process of imagining a community, as it 1) reconfigures the complex politico-economic and cultural contradictions shaping the crisis of Texas annexation as a manageable, functional, political opportunity to realize the United States' national "destiny," while 2) vigorously avoiding the fact that Texas' slave-based cotton-economy was responsible for profound inequalities. While 30 percent of Texas' white population owned slaves, 72 percent of Texas' real property, and 89 percent of the state's lucrative cotton market, only 2.3 percent of Texas' white population owned 20 -or-more slaves (widely considered the general dividing line between small-scale farmers and the "planter aristocracy"); hence, even within the ranks of Texas' slave-holding whites, property and wealth were distributed in a strikingly skewed manner. ${ }^{2}$ Walker's Letter nonetheless portrays Texas annexation not as an expedient imperialist maneuver to support the politico-economic ambitions of the region's slave-holding elite, but rather as a burning opportunity to extend the "inevitable" promise of the United States' heralded democracy and economic equality. Walker's Letter is therefore a prime example of what Terry Eagleton calls the "actively organizing function of ideology," 3 as it attempts to create both a 
conceptual vocabulary and a revisionist historical narrative capable of organizing complex subject matter into a digestible fiction that appears laden with the readymade historical legitimacy of national "destiny." Walker's letter is thus a case study in the rhetorical "logic" of rationalizing imperialism.

My analysis progresses in three sections. Part one offers a broad historical framework that situates the debate surrounding Texas annexation within the larger political battles regarding national expansion and slavery. Part two begins by contextualizing Senator Robert Walker within the political milieu of Jacksonian Democracy and the Presidencies of Tyler and Polk, and then proceeds to a close textual analysis of the five primary theses of the Letter. Part three then concludes the essay by offering observations on the relationships among Walker's Letter on Texas Annexation, the sweeping cultural, technological, and political changes attendant upon the development of what Anderson calls "print capitalism,"4 and the development of a rhetorical "logic" rationalizing the United States' imminent march towards "eventual continental dominion." This essay thus constructs an interdisciplinary culture studies framework that engages in a detailed textual analysis of Walker's Letter while simultaneously grounding this reading within the materio-historical context of the United States' "progression" into modernity. As such, I limit my comments on United States diplomatic intrigue, and focus instead on Walker's Letter as an example, even an allegory if you will, of a rapidly modernizing nation struggling to comprehend and rationalize its ascendancy as one of the world's dominant imperialist powers. ${ }^{6}$

\section{Historical Background: Why Annex Texas?}

Between 1790 and $1865,835,000$ slaves were relocated westward, with 85 percent of these "exports" initiating from the once dominant tobacco, sugar, and rice-based plantations of Maryland, Virginia, South Carolina, and North Carolina. Approximately 75 percent of these relocated slaves ended up on the cottonbased plantations of Alabama, Mississippi, Louisiana, and Texas. ${ }^{7}$ This massive transfer of slaves enabled a remarkable increase of cotton production in these states; indeed, by 1860 the U.S. Census reports that Alabama, Mississippi, Louisiana, and Texas account for over 63 percent of all United States cotton production. ${ }^{8}$ There is little question then, that the political-economy of cotton was pulling slavery southwestward.

The shifting of such dramatic numbers of slaves to the southwest was consistent with the gradual realignment of the economies of the border states of Kentucky, Missouri, Maryland, and Virginia, which were evolving in directions similar to those of the North, complete with labor forces of increased numbers of European immigrants and migrating laborers from the North. Laurence Shore argues in Southern Capitalists that opening up the economy to wage laborers indicated that the border states were undergoing "a pattern of economic development that began to pull them closer to Pennsylvania and Illinois, and further from 
Mississippi and South Carolina." According to Shore, certain critics even suggested that this "pattern" pointed toward the eventual demise of slavery as a viable politico-economic system; Texas was therefore crucial to how the United States understood the cultural and politico-economic consequences of this pattern, as Texas was touted as the promised land for the perpetuation of slavery. Indeed, between 1840 and 1850 the Texas slave population grew from 12,507 to 48,145 ; by 1861 the slave population was over 169,460 , an increase from 1840 of 1300 percent. ${ }^{10}$ The slave population of Texas was small compared to that in Alabama and Georgia, but the growth rate was phenomenal, leaving little doubt in the minds of the planter elite that Texas was, as noted Texas historian Randolph Campbell describes it, "slavery's frontier."

Texas was also a frontier of another sort, as it was a constant hot-spot for military confrontations between westward white settlers, indigenous peoples, Mexican landlords, and pirate slave dealers. ${ }^{12}$ As early as 1819 , a hodge-podge of squatters, mercenaries, and miscellaneous troops, under the leadership of James Long, a one-time student of Andrew Jackson, marched from Natchez to Nacogdoches to do battle with Mexican troops in the hope of establishing the Republic of Texas. Long's troops were stomped, but the Texans later won their "independence" in the infamous eighteen minute battle of San Jacinto, 21 April 1836. Mexico in 1837 yet again abolished slavery, which meant that the continent's newest nation-ripe with the potential to become the most profitable slave-based cotton-economy in the world-was bordered not only by an enemy nation, but by one whose unpoliced hinterlands offered nearby refuge for runaway slaves. ${ }^{13}$ It is no surprise then, that Indians, Mexicans, and runaway slaves-all with legitimate grudges against the Texas cotton elite-formed temporary alliances to do battle with Texan slave holders. Indeed, the works of Herbert Aptheker, Wendell Addington, Paul Lack, and Richard Maxwell Brown suggest that such battles were a constant part of life on the Texas frontier, as the expanding geo-political agenda of the cotton elite and the attacks of settlers on existing Mexican and Indian land-claims produced a perpetual war economy of roving militias, squads of vigilantes, and gangs of drunken thugs. ${ }^{14}$ Noted American-Indian historian Ward Churchill reports that Texan/Indian violence was so prevalent that "the government of first the Republic, and then of the State of Texas, maintained a bounty on all Indian scalps until well into the 1870s."15 There is no question then, that Texas was the new frontier not only for the political economy of slave-based cotton production but also for the many forms of military conflict and Indian removal that were so central to the cultural fictions "explaining" Manifest Destiny.

Texas was simultaneously a frontier of yet another sort, as it was a constant site of confrontation between the United States and its European competitors, particularly Britain. For example, the British had tried desperately to grow cotton in India, in order to offset the United States' international monopoly; when that venture failed, they turned towards Texas as a potential colony and/or politico- 
economic ally. England was not alone in this thinking, as Texas had (by 1842) established formal diplomatic relations not only with England, but also with France, Holland, and Belgium. Such Texas/European commerce was so profitable, and the promise of continued European demand for cotton so definite, that Texas President Sam Houston boasted in December of 1844: "If we remain an independent nation, our territories will be extensive-unlimited ... the Pacific alone will bound the mighty march of our race and our empire."16

There is little question then, given the intense emotions surrounding the debate over slavery's future, along with the perceived threat of imminent British adventurism, recurring Indian violence, and Houston's big talk regarding the imperial future of an independent Republic, that the push for Texas annexation was in great part a response to what was perceived as an impending crisis. No less a public hero than ex-President Andrew Jackson claimed that Texas annexation was a necessary defensive measure to protect the Union from the triple threat of British economic and military invasion, raids by savage Indians, and slave insurgency. Jackson feared that this unholy alliance, if left unchecked, could "raise a servile war, take New Orleans, arouse the Indians on our West to war, and throw the whole West into flames that would cost oceans of blood and hundreds of millions of money to quench and reclaim." ${ }^{\prime 17}$ It is not difficult to imagine how such apocalyptic rhetoric aroused the anxieties of the South; it is confusing, however, to try to fathom how such predictions of regional catastrophe addressed the interests of Northerners.

One response of the Southern cotton elite was to portray Texas annexation not as a desperate situation of crisis management but rather, as a golden opportunity for economic advancement. For example, Democratic Senator Ambrose Sevier of Arkansas argued before the Senate on 7 June 1844 that "The annexation of Texas will enable us to monopolize, through the instrumentality of slave labor, the production of cotton and sugar. . not only for our own markets, but the markets of the world." ${ }^{18}$ Such grand talk of global monopolies was no doubt appealing to both Southern capitalists and their business partners in the North, yet by including "the instrumentality of slave labor" as one of the prerequisites of this economic boon, Sevier corroborated Northern fears that Texas annexation was but another maneuver to bolster the fortunes of the "peculiar institution." As early as 1836 Benjamin Lundy argued that U.S. interest in Texas resulted from "a long premeditated crusade against the government set on foot by slaveholders, land speculators, etc., with the view of re-establishing, extending, and perpetuating the system of slavery." 19 Both Jackson and Sevier argued for Texas annexation in terms that so clearly represented the exclusive concerns of the South's slave-holding cotton-producing elite that they literally confirmed the worst suspicions of anti-expansionists such as Lundy. It is clear, then, that constructing a cultural fiction that could enable a nationwide consensus on the issue required the use of more inclusive rhetoric. In other words, a hegemonic pro-annexation front could not be built by using such obviously and 
exclusively pro-"slave power" arguments, but instead, required the production of pro-annexation arguments that would appeal to both small-scale Southern farming and Northern concerns as well.

This is where race becomes a key issue: by linking the annexation of Texas as a necessary defensive measure to protect the Union with ever-present Northern racial fears, pro-annexation propagandists were able to produce a cultural fiction of an apparently national perspective. Indeed, one of the crucial factors in articulating this cultural fiction as a national concern was the claim that Texas would act as a "safety-valve" that would absorb westward moving slave labor and eventually channel Africans down into Latin America. For example, South Carolina's Democratic Senator George McDuffie argued, along with Senator Walker, that "if we annex Texas, it will operate as a safety-valve to let off the superabundant slave population from among us." ${ }^{20}$ The promised removal of Africans from "among us"-clearly an appeal to racist sentiments in both the North and the South, as well as to the dominant Northern anxiety over wage depression - transformed what was essentially a defensive reaction to a regional politico-economic crisis into a proactive cultural fiction of national proportions.

My thesis then, is that 1) the arguments discussed above as rationales for annexing Texas_-Jackson's "necessary defense" argument, Sevier's vision of a slavery-based global monopoly on sugar and cotton production, and McDuffie's "safety valve" theory-were preliminary attempts to articulate a cultural fiction broad enough to coalesce the various regional and class-based elements of the debate into a unified, hegemonic bloc, and that 2) the spectacular success of Senator Robert J. Walker's Letter on Texas Annexation followed from Walker's ability to incorporate the limited regional elements mentioned above within an even more grandiose, unifying, national cultural fiction that portrayed Texas annexation as the epic work of pre-ordained historical destiny. ${ }^{21}$

\section{Senator Walker's Letter on Texas Annexation}

Robert Walker graduated from the University of Pennsylvania in 1819 at the top of his class. By 1822 he was an established lawyer in Pittsburgh, apparently well on his way to fulfilling the legacy of his father, a distinguished Pennsylvania Supreme Court Judge and veteran of the Revolutionary War. Then, in the Spring of 1825, Walker married Mary Blechynden Bache, the great-granddaughter of Benjamin Franklin and granddaughter of A. J. Dallas, James Madison's Secretary of the Treasury. Ms. Bache was also the niece of George Mifflin Dallas, who, at the time, was a prominent pro-Jackson Democrat in Pennsylvania politics. Walker was thus privy to the inner sanctum of the rising Jackson movement, with which he had been active since 1822. In 1826 he moved to Natchez, Mississippi, where he began a lucrative law practice and, courtesy of Jackson's decimation of the Choctaws and the ensuing 1833 Treaty of Dancing Rabbit Creek, which opened vast amounts of Western lands for bargain (and some say illegally rigged) 
prices, embarked on massive dealings in Western land speculation. Walker then parlayed his legal and financial successes, along with his strong family ties and much-publicized letters of support from King Andrew, into politics; he arrived in Washington in 1836 as a Democratic Senator from Mississippi. In 1841 he was re-elected and returned to Washington as one of its most respected power brokers, complete with the flattering title "The Wizard of Mississippi." 22

By the time of the Presidential campaign season of 1843/44, Walker had cemented his role as a leading pro-annexation spokesperson, which put him at odds with Martin Van Buren, who, despite his opposition to annexation and his badly fumbling the populist legacy of Jackson, nonetheless appeared a sure bet to win the Democratic nomination. ${ }^{23}$ The Presidency of John Tyler-who was universally condemned as "His Accidency" after he ascended to the Vice Presidency as a "reconciliation candidate" to Southern Whig swing-votes and then to the Presidency after the death of William Harrison-was a crippled embarrassment, leaving little doubt that Henry Clay would receive his party's nomination for President. Pro-annexation Democrats thus needed to find someone other than the eagerly waiting Van Buren who could defeat the Whig's Clay. The problem, however, was that annexation was still primarily a backburner issue, as Van Buren was fastidiously ignoring the question in the hope that he could return to the White House without having again to combat the imperial legacy of his legendary predecessor, while Clay, too, wisely avoided the issue for fear of its potentially divisive appeal to sectional rather than party allegiances. ${ }^{24}$

It is not clear how this happened because both Van Buren and Clay seemed assured of their nominations and mutually pledged to silence on the potentially explosive issue of annexation (what Freehling calls "do-nothingism"! (25 $^{25}$ but a coterie of pro-annexation Democrats somehow persuaded the lame-duck Tyler to postpone the Democratic convention from November 1843 to May $1844 .{ }^{26}$ According to David Pletcher in The Diplomacy of Annexation, this inexplicable postponement gave Walker and pro-annexation Democrats the crucial window of opportunity needed to launch Texas into the national consciousness. The strategy was to torpedo the nomination of Van Buren (who was, after all, a much-loathed back-room banking man from New York) as a first step towards securing the nomination for a properly imperialist Southern gentleman, who, ultimately, would grease the political wheels for the immediate annexation of Texas. ${ }^{27}$

Walker's most important contribution to this agenda was his Letter of $M r$. Walker, of Mississippi, Relative to the Annexation of Texas, first published in the Washington Globe on 3 February $1844 .{ }^{28}$ The Letter was an unparalleled media sensation, reprinted in the millions not only in the Washington Globe, Philadelphia Pennsylvanian, and New York Herald, but also in privately funded chapbooks and pamphlets that, according to Frederick Merk, were "subsidized by a secret 'Texas Fund' established in Washington by wealthy Southerners and speculators in Texas lands." ${ }^{29}$ Walker's Letter was thus a privately funded piece of propaganda charged with the dual task of throttling Van Buren in order to open 
the door for a pro-annexation Southerner to win the Democratic nomination and of drumming up national concern for Texas annexation. Walker was thus a proannexation ringleader in his own right and a hired propagandist in the pay of the plantation elite; his Letter, then, was written for the specific purpose of producing a cultural fiction capable of 1) dramatically realigning the power structure of the Democratic party, and 2) articulating a unified "national" response to a series of politico-economic and cultural crises that were, as detailed above, fueled by contradictory regional anxieties. ${ }^{30}$

Walker delivered on his task: the Democratic Review wrote that "The letter has been more extensively read and circulated, and produced a more powerful and decided effect upon the popular mind, than any publication of an American statesman of the present day." The Review even claimed that the Letter was "the principal cause in ... the nomination and election of Polk to the Presidency." 31 The previously unheralded James Polk (during the campaign, disdainful Whigs mocked him with the chant "Who is James K. Polk?") won the Democratic nomination for President, with Walker's old political-guardian and blood relative, G. M. Dallas, chosen as Vice President. It comes as no surprise that Polk and Dallas, who were both ardent expansionists, appointed Walker to head their campaign committee in Washington and later, after winning the election, appointed him Secretary of the Treasury.

The problem for Polk and the pro-annexation Democrats, however, was that although they managed to win the Presidency, the combined Northern votes for Clay and the Liberty Party's James K. Birney, both of whom ran on nonannexation platforms, surpassed Polk's total by $47,462 .{ }^{32}$ In fact, Frederick Merk argues that if Birney voters had not fled the traditional Whig Party, "Clay would have carried New York and Michigan, and would have won in the Electoral College by a margin of 146-129." 33 Furthermore, the lame-duck Tyler had already presented an annexation treaty to Congress that was soundly rejected in June of 1844. Thus, while there was neither a sweeping "mandate" for Polk nor for pro-annexation sentiments either before or during the early stages of the election campaign, Texas annexation was nonetheless approved by the House on 25 January 1845 and then by the Senate on 27 February 1845, six days before Polk's inauguration. The question then, given this maddeningly complex political situation, is how did Walker's Letter achieve its remarkable "effect upon the popular mind?"

I will attempt to answer this question by addressing Walker's Letter as a prime example of what Dubravka Ugresic describes as "national mythomania." Specifically, Ugresic describes national mythomania as the fundamentally modernist process by which the function of "building a new state, a new truth, of establishing the continuity of national identity," is pursued via the "distorting, touching-up, or counterfeiting of history." 34 This is not to suggest that Walker simply strays from some organic bedrock of historical truth, for it is a foregone conclusion that all histories strive, at some level, to re-create the world according 
to their historically specific cultural, political, and national assumptions and agendas. Rather, I want to examine his 1844 Letter as an attempt to produce a rhetorical state of "national mythomania" through the conscious manipulation of racist stereotypes, nationalist and imperialist fantasies, and subtle historical subterfuge of various forms. None of these strategies would work, of course, unless they somehow captured the imagination and rang true, as it were, with at least a large portion of the voting U.S. population. My purpose then, is to examine how Walker's Letter managed to construct one version of reality, one particular cultural fiction, that was, for a multitude of cultural and political reasons to be analyzed below, and in conjunction with a variety of specific historical factors to be examined below, taken by its contemporaries to be so persuasive.

Walker begins his Letter with a nifty shift of vocabulary, as he states that he is "in favor of the $r e$-annexation of Texas." Texas, as Walker sees it, "was once our own" (225:2), but was unforgivably "surrendered" as part of the Adams-Onis Treaty of $1819 . .^{35}$ Thus the question of annexing Texas is, for Walker, "a question of the re-establishment of our ancient boundaries, and the $r e$-possession of a territory most reluctantly surrendered" (226:2, my emphasis). Texas annexation then, "is not a question of the extension of our limits, but of the restoration of former boundaries. . . of reunion" (228:2, my emphasis). Each of these lines attempts to shift the question of Texas annexation from the realm of expansion, annexation, aggrandizement and, in short, imperialism, to the realm of reclamation, restoration, and reunion; that is, the United States is not robbing and pillaging Mexico, but simply and humbly "pursuing our ancient and rightful boundaries" (228:1). Pursuing this line of rhetorical revisionism, later editions of the Letter incorporated "reannexation" into the title. Walker of course realized that these boundaries were scarcely old, let alone "ancient," which perhaps explains his arguing so strongly for these so called "ancient boundaries" as being rightfully won in battle against "the usurper Santa Anna" (223:1). Indeed, it was in 1836 that, according to Walker, "The people of Texas resolved to resist, and perish upon the battle field, rather than submit to the despotic sway of a treacherous and sanguinary military dictator" (223:1, emphasis added). Walker explains that "short was the conflict, and glorious the issue," and that "The American race was successful" (223:1). Walker concludes his historical introduction by claiming that, having won their freedom from Santa Anna, "The people of Texas, with unparalleled unanimity, decided in favor of annexation" (223:2, emphasis added).

So, to summarize his opening arguments, Walker attempts to interpellate the diverse and often antagonistic populations of Texas into one homogeneous PEOPLE, complete with a unanimous will, who are already citizens of the United States by right of the "ancient" boundaries established both in the Louisiana Purchase of 1803 and then again in the heroic 1836 overthrowing of the "usurper Santa Anna." These republican warriors for freedom are, as Walker reminds his readers, members of "the American race." Texas annexation then, when framed 


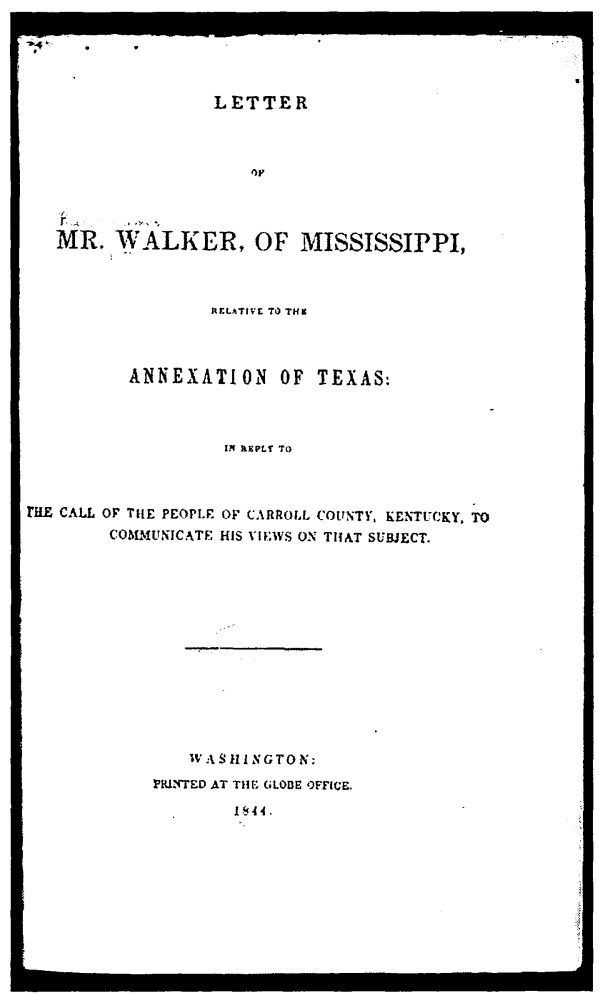

Figure 1: Walker's 1844 Letter on Texas Annexation repeatedly prophesies the imminent continental dominion of the United States. For example, after spending the first few pages of the pamphlet blessing America and attacking both Britain and Mexico, Walker claims that "Of all the forms of government, our confederacy is most specially adapted for an extended territory, and might, without the least danger, but with increased security, and vastly augmented benefits, embrace a continent" (230:1). As support for such grand rhetoric, the Letter closes with seven pages of elaborate tables detailing U.S. economic relations with over sixty-five foreign regions, including the "South Seas," "Peru," "Trieste," "Manilla and Philippine Islands," "Russia," "Australia," "British West Indies," "France on the Atlantic," and even one mysterious destination known as "uncertain places" (250-251). Thus Walker situates his Letter within a modernist discourse that links the fate of national sovereignty and cultural authority to an expansive economic reasoning that transcends geography, political affiliation, and even time itself. (The image appears here courtesy of The Library of Congress.) 
in this light, is an obvious and unproblematic question not of what to do, but of how most quickly and smoothly to open the nation's arms to its racial, historical, and political brothers and sisters.

I should note here that Walker's Letter was but one part of a viciously orchestrated attack against both Santa Anna in particular and Mexico in general. Indeed, the powerful Democratic Review published an essay in September of 1844 that dovetailed nicely with Walker's assault on "the usurper," in which Alexander Everett wrote that "the death of Santa Anna, imperiously and peremptorily demanded by every consideration of humanity and justice, would have been a substantial and permanent benefit to his country." ${ }^{36}$ Prior to the rhetorical attacks launched by Walker and Everett, Thomas Walker Gilmer (the exGovernor of Virginia) published a fiery polemic in the Baltimore Republican and Argus, claiming that

The fashions of dress are not more capricious in their changes than are the forms of the Mexican government. I apprehend it is destined for some time, to continue in a state of civil chaos, giving no sign of energy, but occasional spasmodic convulsions in a body of bigoted priests and mercenary soldiers. ${ }^{37}$

This is not the place for an extended analysis of the sundry rhetorical tropes employed by United States politicians in the long tradition of smearing leaders and nations that stand in America's way; I mention the contributions of Everett and Gilmer toward the demonization of Santa Anna in particular and Mexico in general merely by way of qualifying the effect of Walker's Letter. Put simply, Walker's Letter was so successful in great part because he was able to tap into widely accepted racist and nationalist stereotypes that enabled his attack, in this case on Santa Anna, to ring true as "common sense."

It is equally important to note, before proceeding into Walker's five main theses, that the striking combination of messianic fervor, nationalist aggression, and free-wheeling historical revisionism that structures his introduction is (along with its rhetorical consistency with previous European forms of nationalism), ${ }^{38}$ deeply embedded within the tradition of American exceptionalism, in which treacherous political choices are consistently re-framed as pre-destined historical necessities. Indeed, the rhetorical switch to RE-annexation instead of simply annexation repeats one of the fundamental claims of America's Puritan past. As Sacvan Bercovitch observes in The Rites of Assent, while "Others might stake their colonial claims on royal patents or racial superiority or missionary rights, for the Massachusetts Bay Puritans it was a matter not of claiming rights but of REclaiming ownership." Bercovitch argues that this REclaiming attitude produced a consensus that "migration was a function of prophesy, and prophesy was an unlimited license to expand." ${ }^{39}$ One of Walker's first important rhetorical maneuvers, then, in terms of constructing a cultural fiction that can lure anti- 
slavery Northerners and moderate Southerners into the pro-annexation movement, is to invoke a righteous sense of national destiny and mission that will ring familiar in the ears of the proud historical and political descendants of Puritan New England.

Having constructed the groundwork for his cultural fiction, Walker proceeds into the body of his argument, which, for the purpose of analytic clarity, I have separated into five major theses: 1) annexation embodies the "will" of the Constitution; 2) annexation is a necessary defense against British invasion; 3) annexation will resolve the crises of slavery; 4) annexation will prevent economic collapse; and 5) annexation epitomizes the logic of modernity. In the following pages I analyze these five theses in detail.

\section{Thesis 1: Annexation Embodies the "Will" of the Constitution}

The debates surrounding the annexation of Texas were marked in their early phases by the question of whether Congress had the legal authority to annex an already existing nation into the Union. Walker's first thesis is accordingly an attempt to provide a definitive "answer" to such questions. Walker's constitutional argument is therefore based on a form of hermeneutic wizardry; that is, on his assumed ability, much like that assumed later by Chief Justice Taney in the Dred Scott case of $1857,{ }^{40}$ to decipher the true "intentions of the framers" (224:1). Walker's professed hermeneutic skills allow him to conclude that the Constitution is, essentially, equipped with limitlessly expansive powers of absorption, and that "all the historical facts" (224:2) attest to this power. The crucial point in this first thesis, however, is not that the Constitution is geared for annexation, but more importantly, that such actions coincide with the "intentions" of Presidents Jefferson, Madison, Monroe, Adams, and Jackson, with Henry Clay (Secretary of State under Adams, and leader of the Whig opposition) thrown in for good measure. Walker's first thesis is thus based on the rhetorical trope of metonymy: that is, the "intentions" of a batch of heroes, gleaned through highly selective readings of their diplomatic communications, is magically conflated into the supposed "intention" of the Constitution regarding the issue of annexing new States. To put it another way: the Constitution is made to equal the thoughts and wishes of Jefferson and Madison, et. al., while Jefferson and Madison, et al., are simultaneously made to embody the spirit and letter of the Constitution; anyone opposing the annexation of Texas is therefore not only an anti-Constitution trouble-maker but also a heretic performing a most unholy dance on the graves of the nation's preeminent statesmen. Thus Walker uses metonymy to conflate Texas annexation, the "intentions of the framers," and the wills of various heroic Presidents into one great flaming ball of Constitutional righteousness.

In comparison to similar attempts by his contemporaries to employ metonymy, Walker performs this task exceptionally well. For example, Thomas Prentice Kettell's Southern Wealth begins by asking the reader for "loyalty to the 
Constitution," and ends by asking: "Is it not better to stand by the Constitution and the Laws?"41 The problem here, rhetorically, is that by equating the Constitution with Law, Kettell reveals the Constitution for what it is: specifically, a baffling legal document written by the rich and for the rich in a cunning attempt to persuade the masses to consent to their own disempowerment. ${ }^{42}$ Walker, on the other hand, employs metonymy in order to represent the Constitution not as a numbing icon of indecipherable legalese, but rather, as nothing more nor less than the embodiment of the will of the people. Michael Warner emphasizes the political use-value of such acts of metonymy when he explains that:

\begin{abstract}
Americans pictured law justified by its derivation from the will of the people. The legal-political order would be transcendent in its authority but immanent in its source. The trick was to see how law could be given to the people transcendently and received from it immanently at the same time. ${ }^{43}$
\end{abstract}

My argument then-via Warner-is that this "trick" of textuality and legitimacy, of making the transcendent appear to be derived from immanent sources (i.e., the "People"), is pulled off with great flair through Walker's use of metonymy. Indeed, the various regional conflicts rising from anxieties over slavery and the question of who will benefit, in a politico-economic sense, from the annexation of Texas, are magically conflated via Walker's use of metonymy into a national historico-Constitutional issue of whether or not the current administration will honor the genuine "will of the people."

\title{
Thesis 2: Annexation is a Necessary Defense Against British Invasion
}

Walker's second major argument deals with the threat of British invasion and with annexing Texas as a necessary defense against this possibility. He states that "the present boundary is the worst which could be devised," as "it surrenders the Red River, and Arkansas, and their numerous tributaries, for thousands of miles, to a foreign power." And more: "It brings that power upon the Gulf ... too near New Orleans . . . within a day's sail of the mouth of the Mississippi" (227:2). Walker then reminds his readers that Britain's government is "controlled by her aristocracy, the avowed enemies of republican government," and that "though saturated with blood, and gorged with power, she yet marches on her course to universal dominion" (239:1). The clincher follows: "and here, upon our own borders, Texas is next to be her prey (239:1, emphasis added). Walker then reminds his readers of Britain's various heinous acts in the War of 1812 (236:2237:1), lists its vanquished international enemies-now all servile colonies, and guarantees his readers that "to refuse to accept the reannexation is to resurrender the Territory of Texas ... into the hands of England" (229:1).

Such incendiary rhetoric echoes the previously-cited warning of Andrew Jackson that not annexing Texas would "throw the whole West into flames that 
would cost oceans of blood and hundreds of millions of money to quench and reclaim." There are, however, two obvious problems with this threat: 1) Jackson specifically describes the question at hand as a Western problem, thus articulating the issue as a distinctly regional (rather than a national) crisis; and 2) Jackson includes a crass reference to the millions of presumably tax dollars that will need to be spent to reclaim these Western lands, thereby confirming the suspicions of both Northerners and moderate Southerners that their tax dollars have become little more than a defense fund for the Southwest's cotton elite. Jackson's threat is fundamentally rooted in pro-"slave power" concerns; the cultural fiction is therefore dramatically limited in both its scope and its potential appeal. Walker, on the other hand, drapes his prophesies of the imminent disasters looming on the West within rhetoric that is both nationalist and Biblical. For example, Walker concludes what I am calling his "necessary defense" thesis by issuing a remarkably Biblical warning: "Let all who have aided in producing this dread catastrophe flee the wrath of an indignant nation, which will burst forth like lava, and roll in fiery torrents over the political graves of all who shall thus have contributed to the ruin of their country" (239:2).

What we have here, much as with Walker's use of metonymy to condense the "intentions of the framers" and the "will of the People" within the Constitution, is a gem of rhetorical trickery that would make Jonathan Edwards proud. Indeed, Walker's invocation of Biblical imagery clearly echoes a strategy Bercovitch describes as one of the fundamental tenets of Puritan symbology: specifically, "to give the country a past and future in sacred history, and to render its civic institutions a fulfillment of prophesy." ${ }^{\prime 4}$ In addition to striving for historical and cultural legitimacy via the borrowing of such familiar Biblical imagery and Puritan-ish ideological claims, the more obvious purpose of these mightily exaggerated passages is to expand the question of Texas annexation into a national concern. This maneuver is politically astute, for while the North's rural farmers, members of the working classes, and bourgeoisie might not give a damn about the demise of the Southwest's plantation elite, the return of King George's troops is entirely another matter. Walker's hyperbolic description of the imminent threat from Britain therefore enables him to turn the shimmering cotton field dreams of the Southern plantation elite into a chilling national defense nightmare complete with Biblical overtones; in so doing, he is again successful in portraying Texas annexation, this time as a necessary defense zone against foreign invasion, in terms that conflate divergent regional anxieties into a unified national concern.

It perhaps comes as no surprise, then, considering the rhetorical gymnastics involved in constructing this argument, to realize that Walker may have known full well that England had no such plans for either colonization or abolition. Indeed, in a letter from George Bancroft dated 19 June 1844, Bancroft informs Walker that "England has no desire to colonize Texas or to abolish slavery there; but does desire a monopoly of the Texas market under a virtually exclusive treaty. The issue then is, Texas for the British manufacturers and ship owners... or Texas 
for us by reannexation." " ${ }^{45}$ Bancroft's letter arrived four-and-a-half months after the first publication of Walker's Letter, so it may be the case either that Bancroft's measured analysis shocked Walker into realizing that his original claims were overblown, or that Bancroft's views simply did not correspond to Walker's reading of the situation. On the other hand, their mutual friendship and longstanding correspondence would suggest that Walker, prior to publishing the most important document of his career, would likely have consulted his friend the world-class historian and intellectual regarding England's intentions. If this is the case, then Bancroft's letter may amount to a forceful restating of an ongoing debate between the two men. My analysis of Walker's Letter does not hinge on the question of authorial intentionality, yet the force of the Bancroft letterparticularly when coupled with the fact that rumors of England's intentions were never corroborated with any serious evidence-suggests that Walker's heated representation of England's intentions was not only rhetorical (in the traditional sense of seeking to persuade an audience with powerful language), but perhaps even willfully misleading. It would appear, then, that Walker calculated that hyperbolic threats of colonization and abolition, regardless of whether they may or may not have been valid, would trigger more politically-expedient chestthumping than would guarded discussions of market shares.

Regardless of the level of Walker's conscious subterfuge, I again note that his Letter was so successful in constructing this "necessary defense" argument because, in great part, it was able to tap into and was reinforced by a series of related cultural fictions. For example, Walker's Letter received considerable support from the Democratic Review, which echoed the necessary defense argument in its July 1844 edition, where it warned: "To abandon Texas now is to invite for her British Protection and British Policy. It is to close round us the circle of British Power." ${ }^{46}$ Furthermore, during the Summer directly preceding publication of the Letter, it was widely publicized that on 18 August 1843, in England's House of Lords, Lord Aberdeen (the Foreign Secretary) and Lord Brougham openly debated the issue of how England might influence the Texas situation. Reports of this debate (which reached America via the packet ship Victoria on 19 September) ${ }^{47}$ particularly when coupled with the fact that the controversial World Antislavery Convention convened in London that same Summer, clearly helped foster an environment of fear that was succesptible to Walker's hyperbolic claims that England was conniving to lure Texas from the fold. ${ }^{48}$ Indeed, news of the Antislavery Convention and the House of Lords debate contributed substantially to the widely accepted, whether correctly or not, notion that England was secretly maneuvering for the abolition of slavery in Texas, and that immediate U.S. action was therefore required to prevent Texas from drifting further into the dreaded path of England's "march to Universal domination." Thus, while Walker's Letter was certainly the most widely distributed cultural fiction attempting to spark the sense of an impending national crisis, it is clear that the Letter could not have succeeded in this task were it not for a series of interlocking and mutually reciprocal factors such as the support of the Democratic Review and 
the frantic rumor mill regarding England's supposed abolitionist and imperialist intentions.

\section{Thesis 3: Annexation will Resolve the Crises of Slavery}

One of the dominant fears of the various working classes of the North was that their precarious economic situations would be threatened if large numbers of free Africans migrated into their already unstable communities. Walker was no doubt aware of these fears, so he accordingly warns that ex-slaves migrating northward "might earn a wretched and precarious subsistence, by competing with the white laborers of the North, and reducing their wages to the lowest point in the sliding scale of starvation and misery" (232:1, emphasis added). Walker then launches into an extended reading of the controversial 1840 Census which, to summarize briefly, "proved" that free Africans were ten times more likely than whites to end up in poor-houses, jails, asylums, hospitals, and so on. The Census's conclusions had been thoroughly repudiated as early as 1843, when Edward Jarvis reported in The Boston Medical and Surgical Journal that the Census was a rigged, "fallacious and self-condemning document," yet Walker cites the Census as evidence of incontrovertible scientific fact regarding the unfortunate fate of Africans in a free labor market. ${ }^{49}$ Indeed, Walker links the threat of wage competition with the threat of raised taxes-which the Census proves will be necessary to pay for the "millions of the negro race whom wretchedness and crime would drive to despair and madness" (232:1) — so as to convince further all those who would free the slaves that life after slavery would be, quite simply, impossible.

An equally popular fear of Northerners was that Texas annexation was further evidence of runaway Southern control of national politics. For example, in 1837 William Channing, a Unitarian clergyman from Boston, wrote to Henry Clay that Texas annexation is little more than an attempt "to extend and perpetuate slavery." ${ }^{50}$ Such fears had been expressed the year before in Benjamin Lundy's widely distributed The War in Texas; A Review of Facts and Circumstances, showing that this Contest is the Result of a long Premeditated Crusade against the Government set on foot by Slaveholders, Land Speculators, etc., with the View of Re-establishing, Extending, and Perpetuating the System of Slavery and the Slave Trade in the Republic of Mexico. The calamatous effects of this "premeditated crusade" on the fate of democracy were denounced even more vehemently in Theodore Sedgwick's anonymous 1844 pamphlet, Thoughts on the Annexation of Texas, where he argued that:

The annexation of Texas is but another name for the perpetuity of slavery; and we who now enjoy the rights and hold the soil of the Union, must bid farewell for ever to the hope of relieving ourselves from the danger, the odium, and the disgrace inseparable from this pernicious institution..$^{51}$ 


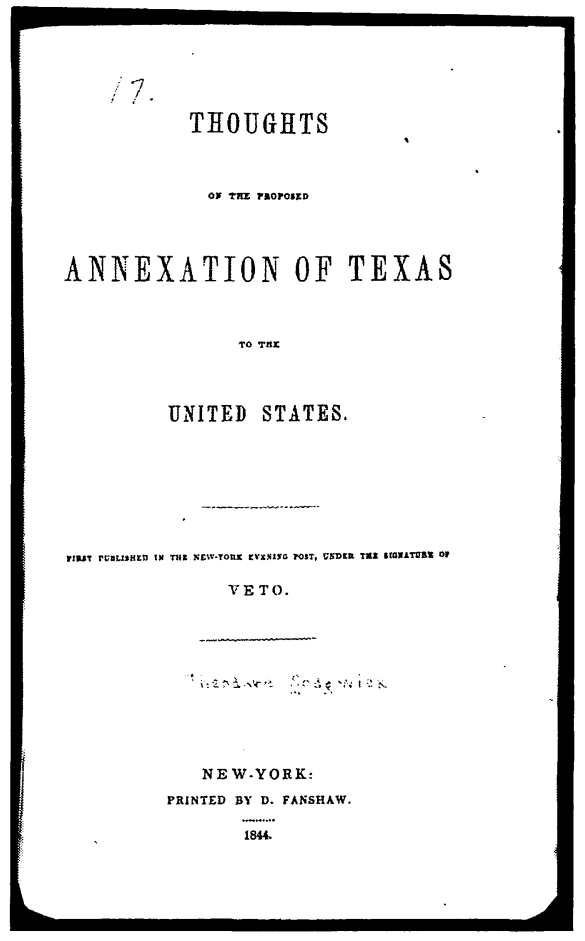

Figure 2: Theodore Sedgwick's 1844 Thoughts on the Proposed Annexation of Texas to The United States demonstrates many of the cultural phenomena described in this essay as marking America's movement towards modernity. Originally published as a series of anonymous essays-attributed to "VETO"-in the New York Evening Post, the pamphlet shown here illustrates the new possibilities of political communication in a world where daily newspapers are beginning to reach mass audiences, where modern printing presses enable the reproduction of printed materials in unprecedented numbers at unprecedented speed, and where the modernizing transportation infrastructure enables the distribution of these materials to distances heretofore beyond the reach of contemporary political debate. In contradistinction to Walker's Letter, Sedgwick argues that annexing Texas is but a ruse "for the sole and only object of perpetuating slavery" (p. 54). (The image appears here courtesy of The Newberry Library, Chicago.)

Channing, Lundy, and Sedgwick each demonstrate aspects of the widespread belief that the annexation of Texas was little more than an excuse for the untrammelled advance of slavery into new territory, and for the final hijacking of democracy itself by slave-power interests. Walker was clearly aware of such 
sentiments, and accordingly "answers" such fears by claiming that Texas annexation is not so much an issue of extending slavery and Southern political power, but rather, the surest and most livable way for the Union TO GET RID OF SLAVERY FOR GOOD.

Walker supports this thesis by citing a series of figures "proving" that slavery is slowly migrating westward, and that it will, if left to its own internal logic, and aided by Texas annexation, "disappear from Delaware in ten years, and from Maryland in twenty, and have greatly diminished in Virginia and Kentucky" (233:2). Walker argues that Texas annexation will not only serve to accelerate this trend, but will culminate in the eventual removal of all Africans from the United States, as "they would be diffused gradually through Texas into Mexico, and Central and South America" (234:1). Walker summarizes this fiction with the magical claim that Texas would be a "safety-valve" that would act as "the only practicable outlet for the African population ... into Mexico and Central and South America" (234:1). On each of these counts Walker attempts to portray the regional politico-economic contradictions involved in Texas annexation in broad national terms that appeal to widespread cultural anxieties regarding race. Thus Texas annexation is turned into a cultural fiction that promises not only the maintenance of white working class wages in the North, but also, the end of slavery in the South and the eventual removal of all Africans from the United States, with the extra added bonus of softening up Mexico and Latin America for future imperialist excursions to follow in the wake of the slave's migration.

Inote again that Walker's Letter received ample ideological support from his pro-annexation colleagues. Indeed, in the opening pages of this essay I cited Senator George McDuffie (Dem./SC) echoing Walker's "safety-valve" rhetoric in the Senate, 23 May 1844. Additionally, the Democratic Review continued its generous support of Walker's Letter when it published an essay in July 1844 claiming that:

Texas will open before it as an outlet, and slavery, retiring from the Middle and Southern States of the present confederacy, will find for a time a resting place there. But only for a time, for the irreversible law of population... will emancipate Texas in her turn, and the negro will then pass to a land of political freedom and social dignity under a congenial sky. He will pass without civil convulsion, and leave no domestic ruin in his path. $^{52}$

Whether any of these promised results were even remotely likely is not the point; what is important is that by projecting the annexation of Texas as a nonconvulsive and non-ruinous step within history's predestined unfolding, Walker (along with McDuffie and the reliable party hacks at the Democratic Review) created a rhetorical space for consensus in which pro-slavery Southerners would 
not feel immediately attacked, anti-slavery Northerners could imagine a progressive resolution of the issue in the not too distant future, and everyone concerned could avoid difficult domestic problems by latching onto the intoxicating promise of the United States' pre-destined role as a hemispheric empire. ${ }^{53}$

\title{
Thesis 4: Annexation will Prevent Economic Collapse
}

Walker's most lengthy passages support the thesis that not annexing Texas will, ultimately, destroy not only the economy of the South, but that of the North as well. For example, Walker states that:

\begin{abstract}
The products of the slave-holding States, in 1840, amounted in value to $\$ 404,429,638$. These products, then, of the South, must have alone enabled it to furnish a home market for all the surplus manufactures of the North. . . Strike down these products by the immediate abolition of slavery, and the markets of the South, for want of the means to purchase, will be lost to the people of the North; and North and South will be involved in one common ruin. Yes, in the harbors of the North the vessels would rot at their wharves for want of exchangeable products to carry; the building of ships would cease, and the grass would grow in many a street now enlivened by an active and progressive industry... One universal bankruptcy would overspread the country (231:2, my emphasis).
\end{abstract}

There is no doubt that the North was making a fortune off of its trade with the South, but "universal bankruptcy" was obviously not an option as long as the North could continue trading favorably with Europe. ${ }^{54}$ This is where Walker again plays the nationalist trump card, as he goes into a lengthy analysis of how foregoing the annexation of Texas would hurt not only the North, but also, of equally rotten significance, would bolster the trade of the Unites States' most dreaded European competitors. For example, Walker claims that in 1839 Texas consumed nearly one-fourth of the United States "domestic manufactures," worth some $\$ 1,687,082(243: 2)$. Also in 1839 , however, Texas opened diplomatic relations with France, and then with both Holland and England in 1840, hence opening the door for these European economic rivals to siphon off United States trade. Thus the nice fat trade figure for $1839 \mathrm{dwindled}$, by 1843 , to a paltry $\$ 190,604$ (243:2). There is then, according to Walker's argument, a direct and ominous correlation between the drop in United States profits and the rise of Texas' relations with foreign economic powers. This trend, if left unchecked, will surely result in "Texas becoming a commercial dependent of England" (236:1). And so Walker argues that not annexing Texas will throw the entire nation into economic collapse and pave the way for accelerated European trade with Texas, the downfall of the United States. 


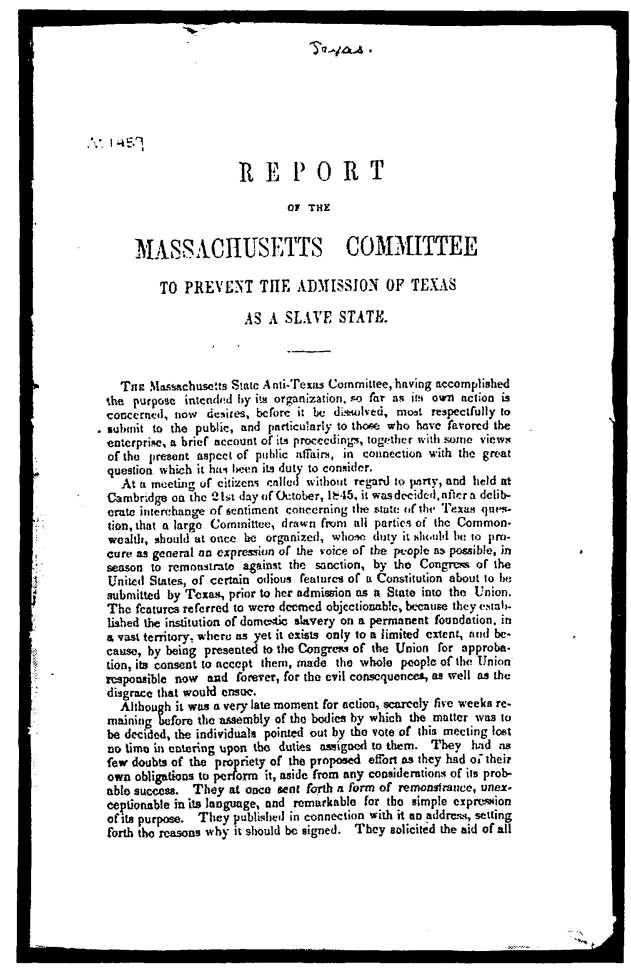

Figure 3: While the cultural, political, and technological transformations of early-modern print-capitalism enabled Walker's Letter to reach millions of readers, they also enabled anti-annexationists and abolitionists to respond in kind. For example, Charles Francis Adams' 1845 Report of the Massachusetts Committee to Prevent the Admission of Texas as a Slave State was circulated throughout New England, New York, Pennsylvania, Indiana, and Ohio, and was then submitted to Congress along with over 100,000 signatures endorsing its arguments. In a move anticipating the rhetoric that would later propel the Republican party to prominence in the North, Adams argues that annexing Texas is "an alarming encroachment upon the rights of the freemen of the Union, a perversion of the principles of republican government, and a deliberate assault upon the compromises of the Constitution" (p. 3). (The image appears here courtesy of The Newberry Library, Chicago.)

It is instructive to note that Walker's nightmarish vision of "one universal bankruptcy" foreshadows the apocalyptic claims of economic disaster presented in such pro-slavery manifestoes as David Christy's Cotton is King (1855), Thomas Prentice Kettell's Southern Wealth and Northern Profits (1860), and 
Stephen Colwell's The Five Cotton States and New York (1861), each of which argued that abandoning the cause of the Southern slave-power elite would produce nation-wide economic collapse. What makes Walker's Letter more convincing as a cultural fiction than these later documents, however, is that Walker's initial question of economic collapse is buried within the even more deeply resonant historical rhetoric of American "unity" vis-a-vis the threat of European economic competition and even military hostility. Walker's economic analysis is so persuasive precisely because he frames it within a cultural scenario that articulates a cross-class, cross-party, and cross-regional alliance of "Americans" against perceived outsiders.

In addition to constructing a rhetorically united American "People" who stand strong in the face of perceived threats from outsiders (and particularly the British), such broad nationalist claims also obscure the fact that Texas is, in contradistinction to the prevailing Jacksonian rhetoric of democracy and economic equality, based on a profoundly unjust economic system. Indeed, as noted in the introduction to this essay, only 2 percent of the population of Texas owned 20 or more slaves (the generally considered the minimum number required for inclusion in the "Planter Aristocracy"), which meant that Texas' economic elites, who accounted for 72 percent of the state's real property and 89 percent of the state's cotton production, were, much like their contemporaries in the rest of the South, in a position of remarkably anti-democratic politico-economic power. ${ }^{55}$ Hence William Freehling's typically wry characterization of pro-annexation extremists as "the minority of despots living within a majoritarian republic," dovetails with his biting assertion that "slave holder republicanism was not very republican when it came to debating slavery." 56 From an economic perspective then, Texas lingered, as a miraculous politico-economic dream of the capitalist elite-whether slave holders in the South or those merchants, manufacturers, and speculators in the North who stood to make a killing off of increased Texas trade-yet Walker portrays the issue as a national crisis of transcendent importance.

The consistent preclusion of discussion of actual economic inequalities in favor of overarching nationalist rhetoric is precisely what Benedict Anderson refers to as the "magic of nationalism," in that it strives "to imagine a community or nation as deep, horizontal comradeship, regardless of actual inequality and exploitation." ${ }^{\text {"57 }}$ It is important to supplement this claim with the realization that Walker's masking of economic inequality via nationalist rhetoric is consistent with one of the fundamental tenets of Jacksonian politics. Indeed, Alexander Saxton summarizes the key Jacksonian practice of plastering over economic inequality with nationalist rhetoric as follows:

Egalitarianism, posed as high principle, requires either a policy of leveling ... or else a denial that differences in wealth carry any invidious significance... (Thus) while Jacksonians made 
no direct effort to eliminate the economic base of class difference, they consistently rejected the concept of class hierarchy as applicable to the American Nation. ${ }^{58}$

Walker's thesis that economic disasters will follow upon the heels of not annexing Texas is permeated with righteous nationalist rhetoric, but does not contain even one reference to the question of whose economy he is talking about. More specifically, his plea for annexation is made from the perspective of a wealthy land speculator who is apparently either unconcerned with or simply ignorant of the fact that such Jacksonian rhetoric, in terms of its relation to the actual distribution of wealth in the U.S., is essentially fictional. ${ }^{59}$ In terms of the rhetorical construction of Walker's cultural fiction, however, it is obvious that speaking in terms of some assumedly egalitarian national economy is more appealing than admitting (as Tyler's Secretary of State, Abel Upshur was fond of doing) that Texas annexation is primarily the work of the Southwest's slaveholding elite. ${ }^{60}$ Thus Walker's Letter reproduces one of the principal ideological tenets of Jacksonian politics, as he avoids any discussion of economic/class differences by masking the economic agenda of the slave-holding capitalist elite within the glowing egalitarian rhetoric of the Nation.

\section{Thesis 5: Annexation Epitomizes the Spirit of Modernity}

Walker's most subtle rhetorical ploy is to portray Texas annexation as part of a grand historical epoch stretching off into the beckoning future. Walker begins this argument by noting that Texas is easily accessible by steam engine, which means that "He who would say that Texas is too large or distant for reannexation to the Union must have been sleeping since the application of steam to locomotion" (231:1). Thus the latest "scientific" breakthrough is enlisted to make Texas annexation appear to be a logical element in the imminent unfolding of history itself. Walker does not actually use the word "modernity" in his argument, yet his propensity-to link "scientific progress" with the political aspirations of the United States, supported by his remarkable hermeneutic ability to decode the hidden logic of history itself-clearly indicates that Walker is attempting to portray Texas annexation as an integral and unavoidable element in the long march of modernity.

Walker portrays Texas annexation, with the help of the mighty steam engine, as foreshadowing the day when the United States will "embrace a continent" (230:1). The natural pull of history will not stop there, however, as "The reannexation of Texas would strengthen and fortify the whole Union, and antedate the period when our own country would be the first and greatest of all the powers of the earth" (235:2). The clincher follows when Walker states that the debate over Texas annexation is "one of the mighty movements in deciding the great question between monarchy and republicanism" (238:2). Thus the 
mechanical power of the steam engine, the heroic expansion of the United States as a continental and even global power, and the Republican battle against European-style monarchies, are all conflated into the pre-ordained logic of modernity. That is, annexing Texas is not so much a question of geo-political expedience and the legitimacy of national sovereignty, but rather, an integral and even inescapable link in the boundless rush of history itself.

It is again important to note that Walker's Letter received ample support in its creation of a cultural fiction that linked U.S. imperial claims to the "natural" pull of history. For example, in April 1844 the Democratic Review published an essay entitled "The Texas Question," in which it prophesied that:

Our system of government is one which, rightly administered-on the principle of State-Rights Theory-will bear indefinite extension; nor do we doubt but that in the fullness of time it is destined to embrace within its wide sweep every habitable square inch of the continent. ${ }^{61}$

This is a remarkable passage, for in the midst of a defense of Texas annexation, we also find an endorsement for the essential pro-slavery argument of "state's rights," two references to a future that is already known, and a prophesy without a "doubt" that the United States will not only annex Texas, but, eventually, all of both Mexico and Canada. In comparison to such aggressive proslavery and pro-imperialist claims, Walker's thesis regarding the relation of Texas' fate to the larger sweep of modernity seems almost moderate. The point here is that Walker's Letter was not acting alone, as a stray voice in the wind, but rather, as a carefully crafted element in a larger barrage of manifest destiny propaganda.

\section{Walker's 'Letter," Print Capitalism, and Early U.S. Modernity}

In "Franklin and the Letters of the Republic," Michael Warner observes that:

By the Revolution ... the business of governing relocated itself from the context of town meetings and market-street conversations to the realm of a public constituted in writing and print. The political discourse that ensued was not just a new way of carrying on the same old power relationships: it marked a critical shift in the arena of power. ${ }^{62}$

It seems clear that Walker's Letter may be situated as an example of the dialectic Warner describes above as it achieves maturity: that is, as an example of the "arena of power's" expansion from divergent local, personal, and oral 
levels of political "conversation" into more properly "cultural" and "national" questions engaged predominantly through mass-produced cultural fictions. With this thesis in mind, I conclude by offering some brief observations regarding the relationships among Walker's Letter, the political-economy of print capitalism, and the larger sweep of early modernity within the United States.

It has been amply documented that one of the primary legacies of the Jacksonian era was the initiation of what we would call, using today's language, the culture industry. ${ }^{63}$ For example, Alexander Saxton, in The Rise and Fall of the White Republic: Class Politics and Mass Culture in Nineteenth Century America, notes that in 1830 there were 65 dailies in the United States with an average circulation of 1,200 , selling for six cents a copy, and that by 1840 the number of dailies had risen to 138 , whereas by 1850 this number had ballooned to 254 dailies, with average circulations of just under 3,000 selling for a penny a copy ${ }^{64}$ Saxton points out that these remarkable changes were made possible by the development of new technologies of mass-production, which, by allowing printers to make more papers for less money, enabled the mass production of the first widely circulated daily papers. Based on this analysis, it seems clear that the technological advancements of mass production enabled the famous democratization of the presses that coincided with the rise of Jacksonian Democracy and the urban workingman's movement. ${ }^{65}$

Saxton also reminds us, however, that these new technologies of mass production required massive capitalization; hence his observation that "At one end of this sequence lay a minimal price of entry and a prohibitive unit cost; at the other, a unit curve approaching zero and an investment curve rising almost vertically: mass illiteracy at one end, oligopolistic or monopolized control of communication at the other." 66 There may have been a halcyonic period in which these two curves met in democratic equilibrium, but Saxton concludes his analysis with the sobering realization that, as the political-economy of print capitalism became increasingly undemocratic due to capital accumulation, "egalitarian rhetoric, which for the artisan editors had served as a weapon against the oligarchy, became for their successors a means of obscuring newly developing class separations." 67

There is a crushing (and fundamentally modern) irony here. Specifically, the technologies of mass production that enable the rising capitalist elite to cloak their increasing social power in the disguising rhetoric of egalitarianism and cheap commodities, which I take to be fundamentally non-democratic gestures, simultaneously provide the tangible, visible, and infinitely reproducible evidence, in the form of the mass circulation dailies, that one's friends, neighbors, and fellow citizens are sharing in the same social, cultural, and historical space, which I take to be the bedrock sense of "here" and "now" that makes the very concept of massdemocracy functional. I am suggesting then, that the radically new means of mass production and distribution that we associate with the first phases of modernity enable a strange act of synecdoche, in which the mass-circulation of a text, which, 
it might be thought, should lead to alienation and displacement, actually enables the individual reader to imagine him or herself, via his or her participation in the shared world conveyed in the text, as a member of some larger "imagined community." Indeed, as Benedict Anderson describes this process, "each communicant is well aware that the ceremony he performs (in reading the paper) is being replicated simultaneously by thousands (or millions) of others of whose existence he is confident, yet of whose identity he has not the slightest notion. ... What more vivid figure for the secular, historically clocked, imagined community can be envisioned?" 68

In this sense then, Walker's Letter (which sold in pamphlet form for \$3-perhundred, or three cents each) needs to be understood as a wonderfully illustrative example of one of the most important aspects of early United States modernity: specifically, the Letter marks the convergence of the new technologies of mass production that prompted the growth of print capitalism with the nationalist imperative for imperial expansion. ${ }^{69}$ Indeed, if we accept the premise that modernity is distinguished from previous historical moments by its use of technologies of mass-representation to launch "imagined communities" beyond the barriers of geography, language, and ethnicity, then it follows that Walker's Letter, the single most widely distributed piece of imperialist propaganda of the period, unmistakably announces the rise of modernity in mid-nineteenth century America. ${ }^{70}$ In short, the Letter signals a dramatic new convergence of political power, in which the technologies of mass-production fueling print capitalism, the geo-political aspirations of the slave-holding elite, Northern anxieites regarding race, and the nation's rapidly accelerating romance with Manifest Destiny find common cause in Walker's rhetorical "logic" of imperialism.

\section{Notes}

1. Benedict Anderson, Imagined Communities: Reflections on The Origin and Spread of Nationalism (London, 1991), 7-11.

2 . The figures on slave ownership and property percentiles are from Randolph Campbell and Richard Lowe, Wealth and Power in Antebellum Texas (College Station, 1977), table 8, p. 38; figure 2, p. 41; and table 9, p. 44. The figures on control of cotton production are from Randolph Campbell, An Empire For Slavery: The Peculiar Institution in Texas, 1821-1865 (Baton Rouge, 1989), 210. The argument that owning twenty-or-more slaves was the approximate dividing line between those slave holders who were little more than local, small-scale farmers, and those plantation-based capitalists who constituted the dominant "planter class" was first put forth in Kenneth Stampp's The Peculiar Institution: Slavery in the Antebellum South (New York, 1956). While Campbell's later study notes that slave holders accounted for 30 percent of the Texas population, 72 percent of its real property, and 89 percent of its cotton production, his earlier work demonstrates clearly that this elite group was itself internally divided: roughly 78 percent of all slave owners held less than 10 slaves, and 14 percent of all slave owners held between 10 and 19 slaves; but 8 percent of all slave owners (or approximately 2 percent of the total White population) constituted the dominant "planter aristocracy" that owned 20 or more slaves.

3. Terry Eagleton, Ideology: An Introduction (London, 1991), 117.

4. See Anderson's discussion of the relationship between "print capitalism" and modernity in Imagined Communities, 22-46.

5. The phrase "eventual continental dominion" is from Albert Weinberg's classic study, Manifest Destiny: A Study of Nationalist Expansionism in American History (Gloucester, 1985), 121 . In her excellent essay, "Dis-Covering the Subject of the 'Great Constitutional Discussion,' 17861789," Journal of American History, 79 (December 1992): 841-873), Carrol Smith-Rosenberg notes 
that the impulse towards nationalist expansion was so prevalent in early American political discourse that President George Washington's 18 June 1783 letter of retirement (published in The American Museum, 1 [Philadelphia, May 1787] "situates Americans as imperialists first and as independent republicans second" (p. 841).

6 . On the question of the diplomatic intrigue surrounding Texas annexation, in both its domestic and international forums, the classic texts are David Pletcher, The Diplomacy of Annexation: Texas, Oregon, and the Mexican War (Columbia, 1973), 113-226; Justin Smith, The Annexation of Texas (repr., New York, 1971, originally 1911); and Frederick Merk, Slavery and The Annexation of Texas (New York, 1972). Thomas Streeter's Bibliography of Texas, 1795-1845, 3 Vol. (Cambridge, 1960) is an indispensable source, as is The Annual Report of The American Historical Association for the Year 1908, Vol. II, Part 1: Diplomatic Correspondence of the Republic of Texas. The best two contemporary analyses are in Thomas Hietala, Manifest Design: Anxious Aggrandizement in Late Jacksonian America (Ithaca, 1985), 10-54, and William Freehling, The Road to Disunion: Secessionists at Bay, 1776-1854 (New York, 1990), 353-452.

7. Robert William Fogel, Without Consent or Contract: The Rise and Fall of American Slavery (New York, 1989), 65.

8. These figures are from The United States 8th Census (1860); also see James Foust, The Yeoman Farmer and Westward Expansion of U.S. Cotton Production (New York, 1975), Appendix I: $208-218$.

9. Laurence Shore, Southern Capitalists: The Ideological Leadership of an Elite, 1832-1885 (Chapel Hill, 1986), 49.

10. See Campbell, Empire For Slavery, 56, and Campbell and Lowe, Wealth and Power in Antebellum Texas, 54-55.

11. Campbell, Empire For Slavery, 4. For less enthusiastic views of Texas' prospects in the early-to-mid 1840s, see Smith's wry comments on pigs roaming the streets of Galveston in The Annexation of Texas, 41 ; chapter 20 of Freehling, Road to Disunion; and Paul Lack, "Slavery and the Texas Revolution," Southwestern Historical Quarterly, 89 (October 1985): 181-202.

12. For example, circa. 1816-1817, the infamous pirate Jean Lafitte, in league with seccessionist factions of Mexicans, used Galveston as a staging ground for seizing Spanish slave ships and then smuggling the (now twice-) stolen slaves into America. See the comments in Campbell, Empire for Slavery, 11-12.

13. Slavery was initially abolished in Mexico in 1823 by President Augustin de Iturbide; however, Iturbide was overthrown that same year, hence plunging the fragile new Constitution (and its anti-slavery clause, particularly regarding Texas) into controversy. The new Constitution for the State of Coahuila and Texas then again outlawed the importation of slaves in 1827, but Texans outmaneuvered this law by bringing slaves into the territory as "indentured servants." Mexican President Vicente Guerrero then again outlawed the importation of slaves from the U.S. to Texas on 15 September 1829; however, by December of that same year Texas' cotton elite had persuaded him to grant Texas exemption from this law. Then, on 6 April 1830, President Anastacio Bustamante issued a decree calling for "the strict enforcement of rules against the further introduction of slaves" (Campbell, Empire for Slavery, 25-27). For two excellent essays on the subject, see Josefina Zoraida Vasquez, "The Texas Question in Mexican Politics, 1836-1845," Southwestern Historical Quarterly, 89 (January 1986): 309-344, and Nettie Lee Benson, "Texas as Viewed from Mexico, 1820-1834," Southwestern Historical Quarterly, 90 (January 1987): 219-291.

14. Nat Turner's rebellion of 21 August 1831, in Southampton County (Virginia), which left over 75 whites and an undisclosed number of Africans dead, is the most well known slave revolt, though it was by no means the largest or the bloodiest. For example, in August 1848 over 75 slaves and some sympathetic whites battled an army of whites in Fayette County, Kentucky. The Texas/ Mexico border, in all of its often-changing sizes and shapes, was another frequent site of pitched battles, the largest of which involved some 1500 runaway slaves and Comanche Indians joining forces against United States troops in the Summer of 1851. This is not the place for an extended history and/ or analysis of the permanent presence of military violence in pre-Civil War U.S.A., but it is important to mention that such mob violence, thuggery, mercenary ventures, lynchings, revolts, border raiding parties, and the everyday violence of whippings and other physical punishments, were a constant reality of the political-economy of slavery. Violence, in its many forms, was not the exception, but rather, the dominant rule, the modus operandi of the culture. See Herbert Aptheker, American Negro Slave Revolts (New York, 1943); Wendell Addington, "Slave Insurrections in Texas" (1950), reprinted in Rebellions, Resistance, and Runaways within The Slave South, vol. 13, Articles on American Slavery, ed. Paul Finkleman (New York, 1989), 2-28; Paul Lack, "Slavery and Vigilantism in Austin, Texas, 1840-1860," Southwestern Historical Quarterly, 85 (July 1981): 1-20; and Richard Maxwell Brown, Strain of Violence: Historical Studies of American Violence and Vigilantism (Oxford, 1975), 301-326.

15. Ward Churchill, Struggle for the Land: Indigenous Resistance to Genocide, Ecocide, and Expropriation in Contemporary North America (Monroe, Maine, 1993), n. 47, p. 71. Churchill notes that the Indian population in Texas plummeted from over 100,000 in 1828 , to less than 10,000 in 1880 (46). 
16. Texas President Sam Houston, speaking before the House on 9 December 1844 , as cited in Hietala, Manifest Design, 51. It is interesting to note that while Houston was publicly talking big in Washington, he was privately begging the United States for military protection from potential Mexican aggression in the event of annexation. For example, in February 1844 William Murphy, the U.S. Chargé in Texas, writes to Abel Upshur, Tyler's Secretary of State, stating that "the President of Texas begs me to request you, that no time be lost in sending a sufficient fleet into the Gulf, subject to my order, to act in defense of the Texan coast in case of naval descent by Mexico" (as cited in Merk, Slavery and The Annexation of Texas, 41). As John Tod tells the story, in a letter to Senator Robert Walker dated 18/23 December 1844, "When sober, Houston was for annexation; but when drunk, or in liquor, he would express himself strongly against the measure!" (as cited in Pletcher, The Diplomacy of Annexation, 177).

24.

17. Andrew Jackson, in a personal letter of 12 April 1844, as cited in Hietala, Manifest Design,

18. Senator Ambrose Sevier, Senate speech of 7 June 1844, as cited in Hietala, Manifest Design,

19. Lundy's charge appears here as it stood as the sub-title (!) to his pamphlet, The War in Texas; a Review of Facts and Circumstances (Philadelphia, 1836).

20. Senator George McDuffie (Dem., SC.), speaking in the Senate, 23 May 1844, as cited in Hietala, Manifest Design, 33.

21. My use of the terms, "articulate," "elements," and "hegemony" is based on the analysis provided in Ernesto Laclau and Chantal Mouffe, Hegemony and Socialist Strategy: Toward a Radical Democratic Politics (London, 1985).

22. The biographical information in this paragraph is taken from $\mathrm{H}$. Donaldson Jordan, "A Politician of Expansion: Robert J. Walker," The Mississippi Valley Historical Review, 19 (December 1932): 362-381; William Edward Dodd, Robert J. Walker: Imperialist (Gloucester, MA, 1967, originally a lecture at the Chicago Literary Club, 28 October 1912); "Robert J. Walker," The United States Magazine and Democratic Review, XVI (February 1845): 157-164.

23. Prior to the Democratic Convention, twenty-four of twenty-six states had already pledged their delegates to Van Buren (see Smith, Annexation of Texas, 235).

24. For an outstanding analysis of Clay's repeated use of such "prudential" moderation, see James Jasinski, "The Forms and Limits of Prudence in Henry Clay's (1850) Defense of the Compromise Measures," Quarterly Journal of Speech, 81 (1995): 454-478.

25. Freehling, Road to Disunion, 427.

26. For discussion of this postponement, see James C. N. Paul, Rift in the Democracy (Philadelphia, 1951), 62-70.

27. For detailed accounts of this story, see Pletcher, The Diplomacy of Annexation, 139-141 ff; Freehling, Road to Disunion, 402-439; Smith, The Annexation of Texas, 234-257; Paul, Rift in the Democracy, 144-168.

28. Robert J. Walker, Letter of Mr. Walker, of Mississippi, Relative to the Annexation of Texas; in Reply to the Call of the People of Carroll County, Kentucky, to Communicate His Views on the Subject, first published 3 February 1844 in the Washington Globe. For the purposes of convenience, the Letter is hereafter cited in my text, by column and page number, as it appears in facsimile in Frederick Merk, Fruits of Propaganda in The Tyler Administration (Cambridge, 1971), 221-252. I have also examined original copies of the Letter at the New York Historical Society and the Newberry Library in Chicago; for a complete listing of locations holding original copies of the Letter, see Streeter, Bibliography of Texas.

29. Merk, Fruits of Propaganda, 123.

30. Later, in 1859 , the Republicans attempted a similar ploy, this time using a shortened version of Hinton Rowan Helper's The Impending Crisis. The Republicans, along with Horace Greeley's backing, and playing off of the topical news of the fierce debate over electing a new Speaker of the House, were, according to Shore's Southern Capitalists, "able to launch Compendium of The Impending Crisis beyond even Harriet Beecher Stowe's Uncle Tom's Cabin in sales and political significance" (67). This view is shared by George Fredrickson, author of the excellent introduction to Helper's Impending Crisis (Cambridge, 1968), where he claims that Helper's Crisis is "The most important single book, in terms of its political impact, that has ever been published in the United States. Even more perhaps than Uncle Tom's Cabin" (ix).

31. The Democratic Review, February 1845, as cited in Merk, Fruits of Propaganda, 125. It is no exaggeration then, when Dodd refers to Walker as "a maker of Presidents" (Dodd, Robert $J$. Walker, 7). For further evidence of the reception of Walker's Letter, it is illuminating to read the correspondence contained in the Walker Papers at the New York Historical Society. For example, the venerable R.W. Johnson (war hero, Senator, Head of the Post Office, and Vice-President under Van Buren) wrote that "I have reread your letter upon the reannexation of Texas to the States. It is a 120pounder-it does your honor \& credit, proving your patriotism, your talents \& your industry. It is a master piece of composition and information" (letter dated 24 February 1844, from White Sulphur, Kentucky; exhibit \# 7 of the Walker Papers). 
32. Freehling, Road to Disunion, 439.

33. Merk, Slavery and the Annexation of Texas, 101.

34. Dubravka Ugresic, "The Culture of Lies," Index on Censorship, 23 (May/June 1994), 39.

35. The Adams-Onis Treaty of 1819-to use Walker's term-“surrendered" Texas to Spain. There was in fact much controversy over the boundaries of the Louisiana Purchase of 1803, so the debate over whether Texas was to be annexed or REannexed could be traced back to the various machinations surrounding this previous land-deal with Spain. What Walker does not mention, however, is that the Adams-Onis Treaty-whether it surrendered Texas or not-secured vast new lands for the United States. As Frederick Merk summarizes the deal, it "Ceded East Florida to the United States, gave recognition to America's seizure of West Florida, and transferred Spanish claims to the Pacific Northwest north of the line at 42 degrees to the United States"- that is, all of the lands that now comprise Oregon and Washington (from Frederick Merk, Manifest Destiny and Mission in American History: A Reinterpretation (New York, 1963), 15). Walker's portrayal of Texas as unjustly surrendered to Spain is thus more than a little deceiving, because Texas was actually used as a bartering chip within a lucrative package deal that, without doubt, favored the United States.

36. "The Texas Question: A Letter from Alexander H. Everett," The United States Magazine and Democratic Review, XV (September 1844), 256. Alexander Everett was a Harvard valedictorian, had been editor of the prestigious North American Review, and was appointed by John Quincy Adams to the important post of Minister to Spain; he was then, one of the North's chosen few, one of the great lettered men of the Republic. His joining the Democrats in 1832 was thus considered nothing less than a defection; this essay from 1844 was therefore doubly powerful as an indictment of traditional Whig politics (see the discussion of Everett in Merk, Fruits of Propaganda, 115-116).

37. Thomas Walker Gilmer, letter to the Baltimore Republican and Argus, 10 January 1843; cited here as it appears [reprinted] in Merk, Slavery and the Annexation of Texas, 203. In reference to Gilmer's letter and the subsequent debates regarding U.S. policies toward Texas following its publication, Smith observes that "the opening gun of a battle seemed to have been fired" (Annexation of Texas, 133).

38. Walker's historical revisionism strives to achieve what Ernest Gellner refers to in Nations and Nationalism (Ithaca, 1983) as "nationalism's amnesia" (57). Along these same lines (regarding nationalism in its European versions), see E. J. Hobsbawm, Nations and Nationalism Since 1780: Programme, Myth, Reality; Second Edition (Cambridge, 1990).

39. Sacvan Bercovitch, The Rites of Assent: Transformations in the Symbolic Construction of America (New York, 1993), 32-33. For further discussion of the relationship between nationalism and the messianic claims of exceptionalism, see Timothy Brennan, "The National Longing for Form," in Nation and Narration, ed. Homi K. Bhabha (London, 1990), 44-70.

40. Concerning the political mischief that follows from such claims of hermeneutic wizardry, Chief Justice Roger Taney's 6 March 1857 majority opinion in the Dred Scott case argued that "Negroes were not intended to be included under the word citizens in the Constitution. And therefore can claim none of the rights and privileges which that instrument provides" (as reprinted in The Civil Rights Record: Black Americans and the Law, 1849-1970, ed., Richard Bardolph (New York, 1970), 17-19).

41. Thomas Prentice Kettell, Southern Wealth and Northern Profits: As Exhibited in Statistical Facts and Official Figures; Showing the Necessity of Union to the Future Prosperity and Welfare of The Republic (1860) (Birmingham, 1965), 7, 173.

42. For a startling analysis of the historical roots of representational democracy, see Edmund Morgan, Inventing the People: The Rise of Popular Sovereignty in England and America (New York, 1988), 153-306.

43. Michael Warner, "Textuality and Legitimacy in the Printed Constitution," The American Antiquarian Society, 97 (1987): 64. For further analysis of this "paradox of legitimacy" within the Constitution (and, by extension, United States democracy itself), see Dick Howard, The Politics of Critique (Minneapolis, 1988), Chapter Four: "Why Return to The American Revolution?'

44. Bercovitch, Rites of Assent, 41.

45. George Bancroft to Walker, 19 June 1844, from Boston, my emphasis; exhibit \#15 of the Walker Papers, New York Historical Society. Bancroft was one of America's first true philosopherkings, as he received a Ph.D from the University of Gottingen in 1820 (when he met Goethe), wrote a remarkable 10 volume History of the United States, served as Polk's Secretary of the Navy, founded the Naval Academy at Annapolis, and eventually was appointed Minister to Great Britain.

46. "The Re-Annexation of Texas," The United States Magazine and Democratic Review, XV (July 1844), 16.

47. See Smith, Annexation of Texas, 123, ff.

48. For discussion of the effect of this debate on U.S. perceptions of England's intentions, see Freehling, Road to Disunion, $397 \mathrm{ff}$. and Merk, Slavery and The Annexation of Texas, $23 \mathrm{ff}$; for an overview of the issue, see Harriet Smither, "English Abolitionism and the Annexation of Texas," Southwestern Historical Quarterly, 32 (July 1988): 193-205.

49. Cited in Albert Deutsch, "The First U.S. Census of the Insane (1840) and Its Use as Pro- 


\section{Stephen Harnett}

Slavery Propaganda," Bulletin of the History of Medicine, 15 (1944), 475. Deutsch's analysis of the 1840 Census led him to the conclusion that it was "one of the most amazing tissues of statistical falsehood and error ever woven together under government imprint" (475).

50. William Channing, in a personal letter to Henry Clay, 1837, as cited in Manifest Destiny, ed. Norman Graebner (New York, 1968), 50.

51. Theodore Sedgwick, Thoughts on the Annexation of Texas (New York, 1844), 38. Sedgwick's pamphlet, published under the name "VETO," is a collection of essays initially published in the New York Evening Post as a response to Walker's Letter. For an equally heated critique of the influence of pro-slave power interests in the debates surrounding Texas annexation, see Charles Francis Adams, Report of the Massachusetts Committee to Prevent the Admission of Texas as a Slave State (Boston, 1845). Both pamphlets are in the Newberry Library, Chicago.

52. "The Re-Annexation of Texas," The United States Magazine and Democratic Review, XV (July 1844), 15.

53. For an historical overview of such promises of imminent U.S. hemispheric dominion, see

Robert May, The Southern Dream of a Caribbean Empire (Baton Rouge, 1973).

54. On the question of Northern capitalists feasting off the labors of the South, see Philip Foner, Business and Slavery: The New York Merchants and The Irrepressible Conflict (1941) (New York, 1968).

55. See calculations in endnote \#2.

56. Freehling, Road to Disunion, $376,377$.

57. Anderson, Imagined Communities, 7 , my emphasis.

58. Alexander Saxton, The Rise and Fall of The White Republic: Class Politics and Mass Culture in Nineteenth-Century America (London, 1990), 144. For further readings on Jacksonian politics, see Edward Pessen, Jacksonian America: Society, Personality, Politics (Homewood, IL, 1969) and Michael Paul Rogin, Fathers and Children: Andrew Jackson and the Subjugation of the American Indian (New York, 1975).

59. On the question of Jacksonian rhetoric vs. actual economic inequality, see Edward Pessen, "The Egalitarian Myth and The American Social Reality: Wealth, Mobility, and Equality in 'The Era of the Common Man'," The American Historical Review, 76 (October 1971): 989-1034; Jonathan Turner and Charles Starnes, Inequality: Privilege and Poverty in America (Pacific Palisades, 1976).

60. For example, Upshur wrote on 13 March 1844 that "The radical defect is in the Constitutional body. How can a country be governed except by those who own it?" (cited as it appears in Freehling, Road to Disunion, 391).

61. "The Texas Question," The United States Magazine and Democratic Review, XIV (April 1844), 429.

62. Michael Warner, "Franklin and The Letters of the Republic," Representations, 16 (Fall 1986), 111.

63. For three divergent perspectives on this issue, see Cathy Davidson, Revolution and the Word: The Rise of the Novel in America (Oxford, 1986); Stuart Blumin, "George G. Foster and the Emerging Metropolis," introduction in New York by Gas-Light and Other Urban Sketches by George Foster (Berkeley, 1990), 1-61; Mary Kupiec Cayton, "The Making of an American Prophet: Emerson, His Audiences, and the Rise of the Culture Industry in Nineteenth-Century America," The American Historical Review, 92 (June 1987): 597-620.

64. Saxton, The Rise and Fall of the White Republic, 95-97.

65. For a remarkable study of working class politics in Jacksonian Democracy, see Sean Wilentz, Chants Democratic: New York City \& The Rise of the American Working Class, 1788-1850 (Oxford, 1984).

66. Saxton, The Rise and Fall of The White Republic, 100.

67. Ibid., 105.

68. Anderson, Imagined Communities, 35.

69. This price is cited in Merk, Fruits of Propaganda, 123.

70. For brilliant example of this thesis, see Ernest Renan, "What is a Nation?," text of a speech presented in Paris, 11 March 1882, reprinted in Nation and Narration, 8-22. For more contemporary perspectives, see Tom Nairn, "What Nations are For," The London Review of Books, 16 (8 September 1994), 7-8, and Nineteenth-Century Contexts, 18 (1994), special issue on "Colonialisms." 